\title{
Fiscal Policy and Deficit Financing: Islamic Perspectives
}

\author{
Habib Ahmed \\ Professor and Sharjah Chair in Islamic Law and Finance \\ Durham University Business School, United Kingdom
}

\begin{abstract}
Using deficit financing by increasing borrowing at lower interest rates has the potential to increase debt to levels that are not sustainable and can create further economic problems in the longer term. To understand the Islamic perspective on deficit financing, two features of government spending need to be recognized. First, government spending can be distinguished as current and capital expenditures. Second, the objectives of fiscal policy and government spending can be viewed as redistribution of income, expenditures to provide government services, provision of public goods that markets fail to provide, and providing infrastructure that enhance the productive capacities in the economies. While current spending should be covered by zakāh (distributive role) and taxes (providing government services and public goods), capital expenditures on infrastructure can be funded by issuing șukuk. During recessions, the government can use counter-cyclical spending of zakāh and tax revenues to increase current spending and issue sukūk to raise funds for investments to enlarge capital expenditures in infrastructure projects. This approach of moving the economy out of recession puts a limit on excessive debt by linking the funds raised with the real economy and helps increase the productive capacity in the longer term by filling the infrastructure gaps.
\end{abstract}

Keywords: Fiscal policy, Deficit financing, Zakāh, Șukūk.

JEL Classification: E62, Z12

KAUJIE Classification: R81, R82, R73 


\section{Introduction}

Ann Pettifor (2019) provides an overview of the debates related to deficit financing and deficit-reduction financing in contemporary economics literature. The former is identified as government spending that leads to larger budget deficits in general. In the latter, government increases spending by taking loans in times of economic downturns to increase income levels which can potentially reduce the deficits and debt. She also asserts that savings are not important since credit can be created without it and that interest rates should be kept low to encourage more lending in the economy. She provides examples from the United Kingdom to support her arguments.

Pettifor's ideas on deficit financing and debt creation can be challenged on a few grounds both from conventional and Islamic perspectives. If one looks at countries beyond the United Kingdom, there are ample cases showing that governments build up excessive debts by deficit financing due to political reasons imposing huge burdens on economies. While this happens in many developing countries, such as recent episodes in Argentina and Pakistan, it can also happen in developed economies as was seen during the global financial crisis when many southern European countries had built up debts that eventually caused serious economic downturns. Furthermore, governments in developing countries often monetize their deficits by printing money that often leads to high inflation. Not only can deficits financed by monetization lead to inflation, they can also increase the fragility of economies whereby negative shocks can cause deep economic recessions.

Pettifor also suggests keeping interest rates low so that lending can be increased to finance the deficits. However, this policy has the possibility of firms and countries falling in a debt trap that makes them vulnerable to crises. When interest rates start to increase, which may be due to higher inflation, the debt burden can increase to unsustainable levels. With high debt levels, higher interest rates can adversely affect the economy since increases in debt servicing can make the countries vulnerable to default. This is particularly the case when the debt is in foreign currency and signs of stress in the economy can result in the depreciation of the currency that further increases the debt burden in terms of local currency. The recent economic turmoil in Turkey shows the problems that excessive foreign debt can cause on exchange rates and economy.

Some of the suggestions of Pettifor can be criticized from Islamic perspectives. To understand the issues related to deficit financing from an Islamic perspective, there is a need to examine the framework of fiscal policy from an Islamic perspective and then present the conditions under which deficit spending can take place.

\section{Islamic Perspectives on Fiscal Policy}

Some Islamic economists have identified the framework of fiscal policies and public finance from an Islamic perspective (for a collection of studies, see Ahmed, Iqbal, \& Khan, 1983 and Ariff, 1982). The bulk of the studies on Islamic fiscal policy, however, revolve around the role of zakāh in redistributing income in the economy. Fiscal policy in an Islamic economy would be a part of the socio-economic policy framework which strives to achieve justice and equity, enhance socio-economic welfare, and induce economic growth (Faridi, 1983, p. 24). Islamic economists such as Umer Chapra and others assert that an Islamic economy would be a welfare state and fiscal policies should focus on development and economic equilibrium. Thus, governments can impose taxes beyond zakāh to achieve the socio-economic goals (Chapra, 1979, 212).

Kahf (1983), however, suggests that there is no evidence of such roles of the state in Sharīah texts and provides a restrictive view on the role of governments to impose taxes to carry out developmental tasks. He justifies taxation beyond the obligatory $z a k \bar{a} h$ in cases of providing the necessary services such as internal and external security, managing the judicial and hisbah apparatuses, maintaining a subsistence standard of living for all citizens, and meeting emergency needs. He also highlights the clear texts that protect private property rights against any encroachment either by individuals or the state. Before imposing taxes, he suggests seeking other sources of income such as rental fee on state-owned property, revenue from public enterprises, public debt, fees, and equity financing of projects. 
Before outlining how the governments should manage their budgets and the role of deficit financing, a few Islamic principles that will guide these issues are presented below:

1. The principle of permissibility (ibāhah) applies in cases of mu 'amalāt which states that in economic affairs everything is permissible except what is prohibited by Sharī'ah.

2. The overriding maxim guiding Sharīah is the maximizing of maslahah (benefits) and reducing the mafsadah (harms) (Heinrichs, 2002; Dien, 2004). Al-Shatibi classifies mașlahah into necessities or essentials (darūriyyāt), the needs or complementary requirements (häjiyyāt), and the luxuries or embellishments (tahsiniya $\bar{t}$ ). The darüriyyāt are essential things for the individuals and community collectively and their absence would lead to a breakdown of social order and community. Al-Shatibi considers the essentials as the basic elements of a good life and protecting them constitutes the goals of the Sharī'ah (maquassid al-Sharī'ah). Al-Ghazali identifies the maqāsidid as safeguarding the faith $(d \bar{i} n)$, self (nafs), intellect ( 'aql), posterity (nasl), and wealth $(m \bar{a} l)$ (Chapra, 2008).

3. The legal maxim "individual losses (or damage) are tolerated to ward off a public loss (or damage)" would imply that the governments can undertake certain activities to reduce harm for the society as a whole even if this would mean that individuals are affected in doing so. For example, imposing taxes which is detrimental to the economic interests of individuals is acceptable if the revenues are used to carry out activities that keep crime in check and maintain law and order which are larger harms in the society.

4. The equivalent of government borrowing to finance deficits in an Islamic economy would be to use different Islamic modes of financing to raise funds. A key feature of these instruments is that they are linked to real economic activities.

The above principles provide the following framework for fiscal policy in an Islamic economy. Since fiscal policy falls under mи'ämalāt, the principle of permissibility would apply. This along with the maxim that social losses be given more weight than individual losses would mean that additional taxes beyond zakāh can be collected, provided certain conditions are met. A key condition is that the taxes should be used to support the achievement of maqāșid al-Sharī'ah since their absence could result in disruption of social order in the society. If the government expenditure exceeds tax revenues in achieving these goals, then Islamic modes of financing can be used to fund the gap. As indicated, a key feature of the Islamic financing would be that it is linked to the real economy.

\section{Deficit Financing from an Islamic Perspective}

While Pettifor argues that deficit-reduction financing could eventually increase income levels and reduce overall debt, the results would depend on not only the quantity, but the quality of the spending. The framework for managing the government budget and deficit financing in an Islamic economy would consider two issues. First, there is a need to distinguish government spending into current and capital expenditures. Second, the rationale of fiscal policy and government spending in the economy can be due to four broad objectives: redistribution of income, expenditures to provide government services such as managing traffic and court systems, provision of public goods that markets fail to provide (e.g., education and health), and providing infrastructure that enhance the productive capacities in the economies.

The redistributive role of the government of an Islamic economy can be carried out mainly by instituting an efficient and effective zakāh collection and distribution scheme. In this regards, zakāh funds can be used to provide the basic living costs of the poor and needy. While this can be a part of the budgetary system, the accounts have to be separated given the specific heads that zakāh can be spent on. The expenditures on government services should be covered by taxes. The way in which public goods can be financed would depend on the nature of these goods and kinds of expenditures required. The current expenditures on heads such as defense, education, and health should be covered by taxes. However, if there is need for building capital assets such as schools and hospitals to provide these services, these can be financed by raising funds by 
using different modes of financing. Finally, infrastructure that promotes economic activity can be financed by both taxes and raising funds from the financial sector. In some countries such as Indonesia and Sudan, the governments have issued sukūk to fund various government projects that include infrastructure.

The above framework of fiscal policy and financing deficits is qualitatively different from the deficit financing presented at the aggregate level by Pettifor. The following perspectives on deficit financing can be viewed from an Islamic viewpoint.

First, the overall framework for fiscal policy should consider a longer time-frame of a business cycle, rather than annual budgets on a year to year basis. Ideally, when the economy is booming, the budget should be in a surplus since the revenues generated are expected to be high and expenditures on social heads such as unemployment benefits would be low. In case an economy is in a recession, it is expected that the expenditure on social heads would increase and it would not be prudent to raise taxes as it could increase the burden on individuals and further slowdown the economy. Thus, the economy should save during upturns that can be used for downturns to cover for some of the deficits. This perspective is in line with the concept provided in the teachings of the Qur'ān when the Prophet Yusuf (peace be upon him) interpreted a dream to mean to save from the seven good years of harvest for the seven years of famine that would follow (Prophet Yusuf, peace be upon him, interpreted the dream of seven fat cows eating the lean cows to mean to the above; see Qur'ān, 12: 43-49). The concept of using $z a k \bar{a} h$ as a counter-cyclical device is also recognized in Islam. It is not obligatory to distribute all zakahh proceeds during a particular time period and a part of it can be used later in cases of depressed economic situations (Ahmed et. al., 1983, p. 14; Yusoff, 2006, p. 117). Furthermore, the government can also solicit advance zakāh payment during recessions in case the needs are dire (National Zakat Foundation, n.d.).

Second, the qualitative nature of deficit financing during economic downturns from an Islamic perspective would be different from Pettifor's proposal that increase expenditure by more borrowing. In an Islamic economy, governments can expand expenditures during recessions by raising funds by using $s u k \bar{u} k$ for investments in the capital assets such as infrastructure. Bielenberg, Roberts, Kerlin, and Oppenheim
(2016, p. 10-24) estimate that US\$ 93 trillion would be needed for investments in sustainable infrastructure during 2015-2030 globally, of which funding in economic infrastructure would amount to US\$ 49.1 trillion (or US\$ 3.3 trillion ann-ually). The funding gap for the period is estimated to be between US\$ 39 trillion (with aggressive invest-ment growth scenario) to US\$ 51 trillion (with conse-rvative investment growth assumption).

Since infrastructure needs and the financing gaps are huge in most countries, using șukūk will be a winwin situation of filling this gap and injecting investment expenditures in the economy. The investments would potentially create jobs that could boost the economy both in the short- and long-terms. Since, raising funds in an Islamic economy is linked to real assets, this imposes a restriction upon using funds on current expenditure which does not expand the productive capacity of the economy. Thus, the funds generated to finance the real sector inhibits the growth of debt levels that become unsustainable.

Finally, the suggestion of keeping interest rates low to encourage borrowing that accumulates debt can potentially pose problems to countries when the interest rates rise. In fact, a key factor in the global financial crisis was the buildup of huge debts in the United States housing sector due to low interest rates which became unsustainable for many when interest rates started to increase. One option that is aligned with Islamic principles of risk-sharing and can bring stability in the economy, is to have returns tied to the performance of the economy such as GDP-linked securities. For example, Diaw et al. (2014) propose a GDP-linked sukūk that can be used to raise funds in a Sharīah-compliant way to finance government expenditure. They suggest using a forward lease (ijärah) contract to structure the $s u k \bar{u} k$ and link the rent paid to the investors to the GDP growth rate.

\section{Conclusion}

Pettifor's suggestion of dealing with recessions by more borrowing that increases debt levels can resolve the problem in the short-term, but can create problems in the long-term. The suggestions that savings are not important and that the financial sector can expand credit without them can potentially add to the problem of debt creation. It should be noted that many contemporary crises have origins in excessive debt levels that become unsustainable when a negative shock emerges. 
The Islamic perspective on fiscal policy and deficit financing distinguishes between current and capital expenditures and argues that the former be covered by zakāh (the distributive role) and taxes (providing government services and public goods), and the latter by raising funds through șukuk. To bring an economy out of a recession, the government can increase current spending by using a countercyclical framework for zakāh and tax revenues

\section{References}

Ahmed, Ziauddin., Iqbal, Munawar., \& Khan, M. Fahim. (Eds.). (1983). Fiscal Policy and Resource Allocation in Islam. Islamabad, Pakistan: Institute of Policy Studies \& International Centre for Research in Islamic Economics.

Ariff, Mohammad. (Ed.). (1982). Monetary and Fiscal Economics of Islam. Jeddah, KSA: International Centre for Research in Islamic Economics.

Bielenberg, A., Roberts, M., Kerlin, M., \& Oppenheim, J. (2016). Financing change: How to mobilize private sector financing for sustainable infrastructure. New York, USA: McKinsey Center for Business and Environment, McKinsey \& Compnay. Retrieved from: http://www.globalinfrastructureinitiative.com/sites/defa ult/files/pdf/Financing_change_How_to_mobilize_priv ate-sector_financing_for_sustainable $\overline{0} \% \overline{2}$ _ infrastructure.pdf

Chapra, M. Umar. (1979). The Islamic Welfare State and its Role in the Economy. In K. Ahmad \& Z. I. Ansari (eds.), Islamic Perspectives, Studies in Honour of Mawlānā Sayyid Abul A'lā Mawdūdī (pp. 195-221). Leicester, UK: The Islamic Foundation.

Chapra, M. Umar. (2008). The Islamic Vision of Development in the Light of the Maqasid al-Shari'ah. Jeddah, KSA: Islamic Research and Training Institute, Islamic Development Bank.

Dien, M.I. (2004). Islamic Law: From Historical Foundations to Contemporary Practice. Notre Dame, Indiana, USA: University of Notre Dame Press.

Diaw, Abdou., Bacha, Obiyathulla I., \& Lahsasna, Ahcene. (2015). Public sector funding and debt management: A case for GDP-linked sukuk. In Hatem collection and increase capital expenditures in infrastructure projects by issuing $s u k \bar{u} k$. This approach can not only help move the economy out of the recession in the short term, but would increase the productive capacity in the longer term through investing in infrastructure projects while putting a limit on creating excessive debt by linking the funds raised with the real economy.

A. El-Karanshawy, Azmi Omar, Tariqullah Khan, Salman Syed Ali, Hylmun Izhar, Wijdan Tariq, ... Bahnaz Al-Quradaghi. (Eds.), Islamic Economics: Theory, policy and social justice (pp. 121-134). Doha, Qatar: Bloomsbury Qatar Foundation.

Faridi, F.R. (1983). A Theory of Fiscal Policy in an Islamic State. In Ziauddin Ahmed, Munawar Iqbal, $\&$ M. Fahim Khan (Eds.), Fiscal Policy and Resource Allocation in Islam (pp. 23-38). Islamabad, Pakistan: Institute of Policy Studies \& International Centre for Research in Islamic Economics.

Heinrichs, W.P. (2002). Qawāid as a Genre of Legal Literature. In B.G. Weiss (Ed.), Studies in Islamic Legal Theory (pp. 365-384). Boston, USA: Brill.

Kahf, Monzer. (1983). Taxation Policy in an Islamic Economy. In Ziauddin Ahmed, Munawar Iqbal, \& M. Fahim Khan (Eds.), Fiscal Policy and Resource Allocation in Islam (pp. 114-135). Islamabad, Pakistan: Institute of Policy Studies \& International Centre for Research in Islamic Economics.

National Zakat Foundation. (n.d.). Payment of Zakat in advance or arrears. Retrieved from: https://www.nzf. org.uk/Knowledge/Calculation_Rules/Payment_of_Za kat_in_advance_or_arrears

Pettifor, A. (2019). 'Deficit Financing' or 'DeficitReduction Financing?' Debates in Contemporary Economics: Origins, Confusions and Clarity. Journal of King Abdulaziz University: Islamic Economics, 32(1), 67-78.

Yusoff, Mohammed. (2006). Fiscal Policy in an Islamic Economy and the Role of Zakat. IIUM Journal of Economics and Management, 14(2), 117-145. 
Habib Ahmed received his M.A. (Economics) from the University of Chittagong, Bangladesh; his Cand. Oecon. from the University of Oslo, Norway; and his Ph.D. (Economics) from the University of Connecticut, USA. Before joining Durham University as Professor and Sharjah Chair in Islamic Finance in 2008, he was Manager, Research \& Development, Islamic Banking Development Group, National Commercial Bank (NCB), Saudi Arabia and also worked at the Islamic Research \& Training Institute (IRIT) of the Islamic Development Bank Group, Saudi Arabia. He also has taught at the University of Connecticut, USA, National University of Singapore, and the University of Bahrain and worked as a visiting professor at the Hamad bin Khalifa University, Qatar. He has authored/edited more than 100 papers and publications, which include articles in international refereed journals, books, chapters in books, and other academic papers/monographs/reports. His research interests include: law and economics, Islamic microfinance, product development in Islamic banks, risk management and corporate governance, zakāh and waqf.

E-mail: habib.ahmed@durham.ac.uk 


\title{
السياسة المالية وتمويل العجز: وجهات نظر إسلامية
}

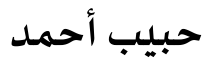 \\ أستاذ كرسي الشارقة للشريعة الإنسامية والتمويل، \\ كلية إدارة الأعمال في جامعة درهام، المملكة المتحداة
}

المستخلص. إن التمويل بالعجز عن طريق زيادة الاقتراض بأسعار فائدة منخفضة قد تؤدي إلى الى المادئ

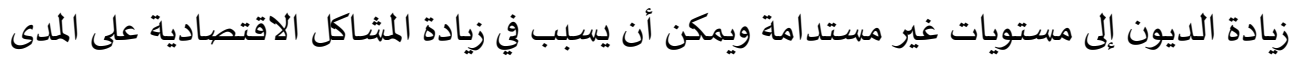

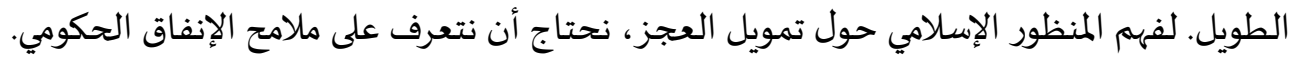

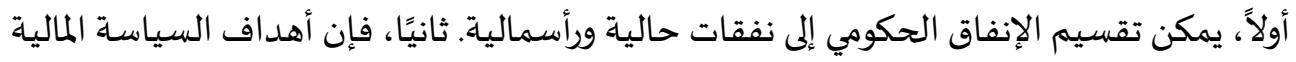

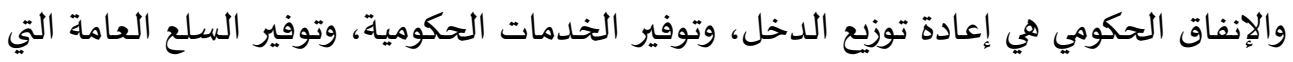

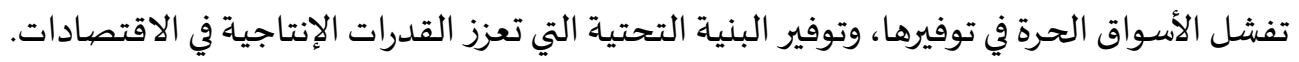

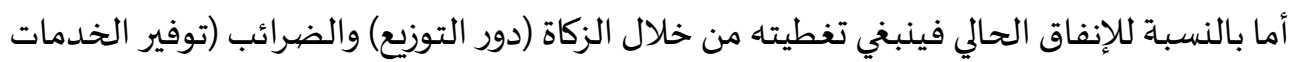

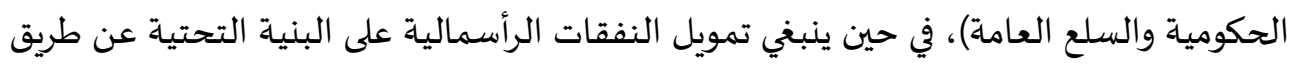

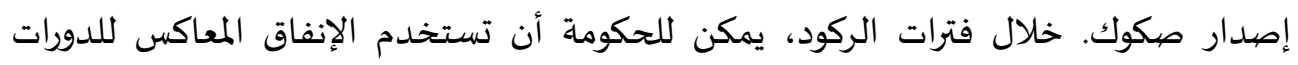

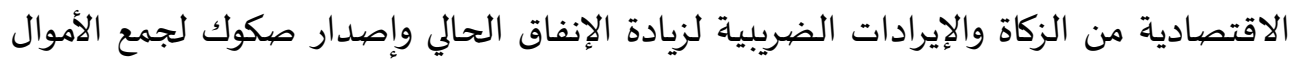

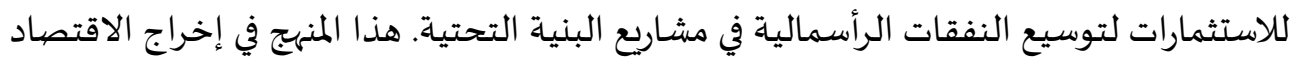

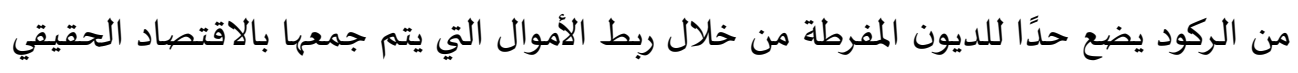
ويساعد على زيادة القدرة الإنتاجية على المدى الطويل من خلال سد ثنغرات المرات البنية التحتية. الكلمات الدَّالة: السياسة المالية، تمويل العجز، الزكاة، صكوك.

تصنيف E62, Z12 تصنيف R81, R82, R73 :KAUJIE 